\title{
Challenging Issues in the Horn of Africa (2016- 2021): The Role of the African Union Commission in Conflict Resolution
}

\author{
Magdalane Malinda Kikuvi \\ Pan African Institute of Governance, Nairobi, Kenya
}

\begin{abstract}
This discussion paper reviews the African Union Commission peace and security achievements in 2020, and outlines the emerging issues in the Horn of Africa, The African Union Commission elected a new chairperson for the term 20212024 in February 2021 and the chairperson is expected to lead the continental secretariat towards achieving the 2021-2024 term plan in line with African Union Agenda 2063. In order to understand the achievements and emerging issues from the Horn of Africa during the period under study, data was collected using desk review and $3 \mathrm{key}$ informant interviews (referred to as $\mathrm{KII}_{1}$, $\mathrm{KII}_{2}$ and $\mathrm{KII}_{3}$ ) from the Horn of Africa region, the African Union and Intergovernmental Authority on Development actors. Data analysis was done using themes. Amidst the first year of the Covid-19 pandemic, the Commission was instrumental in negotiating and requisitioning vaccines for the African Union member States. It has also continued to intervene in Somalia, South Sudan and Ethiopia to ensure peace and stability. However, the emerging issues such as border, and electioninduced disputes, resource-based conflicts, upcoming volatile elections, and external actors in the Horn of Africa have slowed down Commission's mandate. Based on data analysed, to achieve better results at the Horn of Africa, this paper recommends a strengthened political will among the leaders of the Horn of Africa and the empowering of the inter-governmental Authority to intervene in a humanitarian crisis with or without government intervention.
\end{abstract}

Index Words: African Union Commission, Horn of Africa, resource-based conflicts, election-induced disputes, volatile elections, and border-induced conflicts.

\section{INTRODUCTION}

$\mathrm{T}$ The African Union Agenda 2063 objective aims at establishing the highest level of cooperation, a political union, with the creation of a United Africa, actualizing Step 6 of the Abuja Treaty. The Constitutive Act of African Union (AU) Article 20 allows for establishment of the body's commission organ. The Commission's current chairperson took office in February 2021 for his second four-year term since 2017, expected to expire in 2024. It is the African Union Commission (AUC) chair's role to oversee the administration and finance of the Commission, promote and popularize AU objectives, enhance its performance, consult, and coordinate with member States, development partners, and Regional Economic Communities (RECs). Under the ongoing institutional reforms, the Protocol on the Peace and Security Council (PSC) has been merged with African
Governance Architecture, giving the chairperson the mandate to prevent, manage and resolve conflicts in Africa. Although the Commission made various strides during the 2017-2021 term, the chairperson; manifesto argued that not all objectives towards achieving the African Development Blueprint, Agenda 2063 (African Union, 2021) were met. Some of those targeted outcomes included conflict resolution in the Horn of Africa. Some of the AUC achievements in the Horn of Africa are included in Fig. 1.

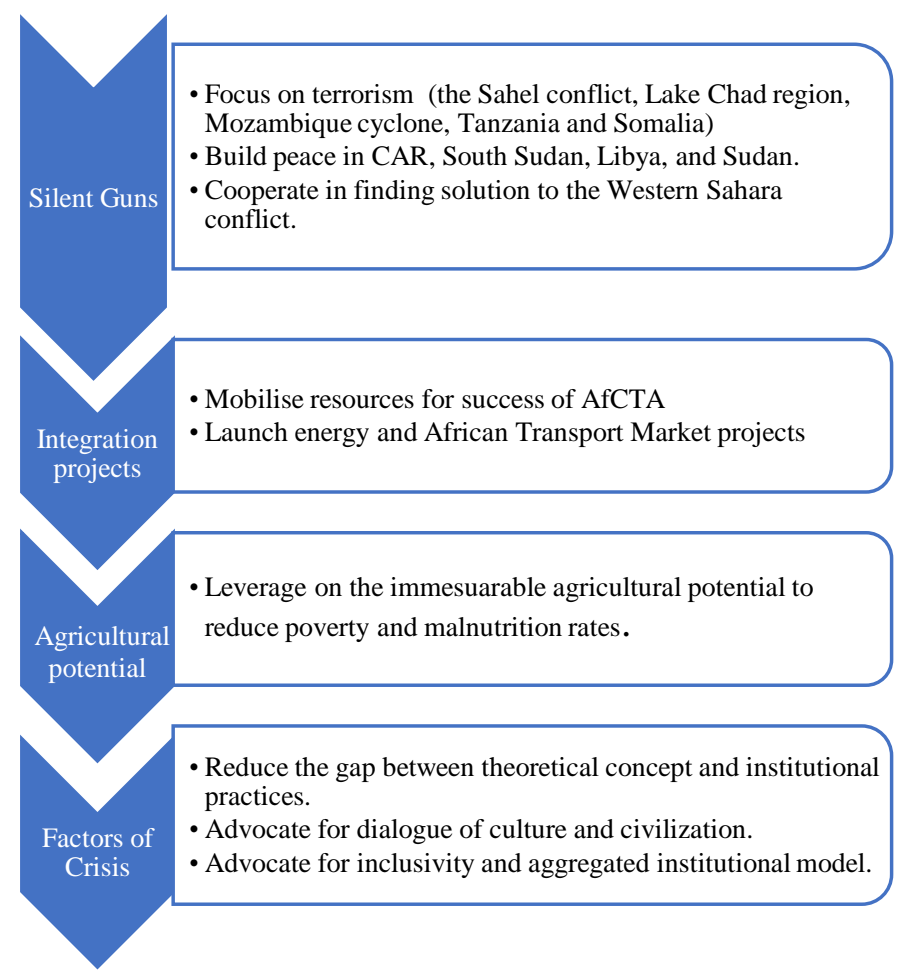

Fig.1Vision of H.E Moussa Faki Mahamat for the Term of Office 2021-2024

Data Source: African Union, 2021

\section{A. Problem Statement}

The AUC has contributed has contributed in the establishment of South Sudan, Sudan, in the overseeing of Somalia's peacekeeping, in the offering medical assistance in the Democratic Republic of Congo (DRC), and in the collective negotiation for Covid-19 jabs. However, its 2017-2021 deliverables were not all met during the first term of the 
current leadership. Challenges included incomplete delivery on the flagship on silencing the guns, the AU theme of 2020, which saw the theme extended to 2030. Moreover, democracy and constitutionalism became a concern as African elections were characterized by violence and loss of lives (African Union, 2021). Furthermore, unconstitutional reforms (Wiebusch et al., 2019) were conducted to allow authoritative regimes to control government beyond the 2-five year-term that is adopted in many African constitutions. In addition, Member States disregarded the African Charter on Democracy, Elections, and Governance, and the effects were manifested in unpaid efforts towards silencing guns in 2020. Therefore, as AUC enters into a new term, such emerging issues of Covid-19, border and election-induced disputes, and bruised diplomatic relations will have to account for its 20212024 report.

\section{B. Research Questions and Objectives}

1) Research Questions:

1. What are the achievements of the African Union Commission in the Horn of Africa amidst the Covid19 pandemic?

2. What are the policy issues emerging from the Horn of Africa?

3. What are the feasible policy recommendations towards achieving better results for the African Union Commission?

\section{2) Research Objectives:}

1. To assess the achievements of the African Union Commission in the Horn of Africa amidst the Covid19 Pandemic.

2. To examine the emerging policy issues in the Horn of Africa.

3. To provide feasible policy recommendations towards achieving better results for African Union Commission member States.

\section{Research Justification}

1. The findings will be significant for policymakers as it underlines the African Union's achievements amidst Covid-19 pandemic and gives the emerging policy issues towards achieving the African Union development plan.

2. The study is timely as it has been conducted when Governments in Africa are struggling to allocate limited resources to curb the spread of Covid-19, hold democratic general elections, and maintain peace and security in the region.

\section{Scope of the Study}

The study focuses on the Horn of Africa region. The Horn of Africa is the eastern peninsula of the African continent. The countries geographically situated in the Horn includes
Ethiopia, Eritrea, Djibouti, Sudan, Somalia, South Sudan, Kenya and Uganda. The paper focused on Ethiopia, Sudan, Kenya, and Somalia.

\section{LITERATURE REVIEW}

\section{A. Theoretical Framework}

\section{1) Theory of Liberal-Intergovernmentalism}

Moravcsik and Schimmelfennig's (1993), liberal intergovernmentalism theory argued that European institutions' intergovernmentalism and decision-making prevailed, despite the integration process's challenges. Like the EU, AU's main direction of integration is liberalization. A common market, a monetary union, and parliament for the African Continent with national States maintain their primary strategic decisions. The theory thus portrays African Union as a regime that produces more efficient inter-State bargaining and enhances national leaders' role. The theory explains the African integration where states have held a higher percentage of power while relinquishing some to a continental body (AU) for enhancing cooperation in social, economic, and political areas. However, intergovernmentalism in the African context has followed a different path from that experienced in the European Union. The African continent is characterized by diverse communities rather than nation States.

\section{METHODOLOGY}

\section{A. Research Design}

The study adopted qualitative-descriptive design. The study is qualitative as it intended to measure variables in conflict resolution.

\section{B. Data Sources}

The study adopted a desk review of African Union official documents and Kenyan Ministry of Foreign Affairs communique. In addition, three key informant interviews were conducted from different AU actors to enrich the study. Data were analysed and presented using themes.

\section{Data collection}

Secondary data was collected from government and regional archives. Primary data was collected using a structured questionnaire administered through telephone interviews.

\section{Ethical consideration.}

Ethical practices were observed during the study. The privacy and confidentiality of the participant's personal information were ensured and protected. The research involved professional respondents working toensure peace and security is attained and restored in the Horn of Africa.

\section{RESULTS AND DISCUSSION}

Objective 1: Achievements

1) African Union Achievements amidst Covid-19 Pandemic 
This section discusses success with regards to management of pandemics in Africa, and the maintenance of peace and security and intra-Africa trade.

\section{Covid-19 Pandemic and Ebola Crisis}

The Africa Task Force for Novel Coronavirus, established in 2020, has helped governments improve screening of the virus and negotiate for a lower price of vaccine for member States. Furthermore, the AU Department of Social Affairs has established an African Strategy against Covid19 and a Covid19 solidarity fund. The fund is to acquire the 670 million doses for 36\% of the African States against the planned 60\% (Obulutsa, 2021). The AU covid-19 Response Fund was launched in March 2020 and had received over USD16,000,000 by December 2020. As listed in the Standard Media website in February 21, 2021, this fund is set to fund the vaccine acquisition. "Africa expects 50 million doses between April and June 2021 and gradual delivery of the remaining doses through 2021 and 2022". AU is acquiring these vaccines for its member States, with Kenya set to receive 11 million doses. AUC has supported DRC in responding to the 11th Ebola virus through the African Centre for Disease Control (ACDC) and Prevention. The 12th outbreak was announced in February 2021, with cases observed in North Eastern DRC, Tanzania, and Guinea. On the other hand, other AU efforts on Covid-19 included the Africa joint Continental Strategy for Covid-19, which was adopted in February 2020 to prevent transmission, deaths and mitigate against social harm (African Union 2021). Moreover, the ACDC established a logistical and supply network that has been instrumental in pool procurement, collection, and distribution of diagnostics and medical supplies across AU member States.
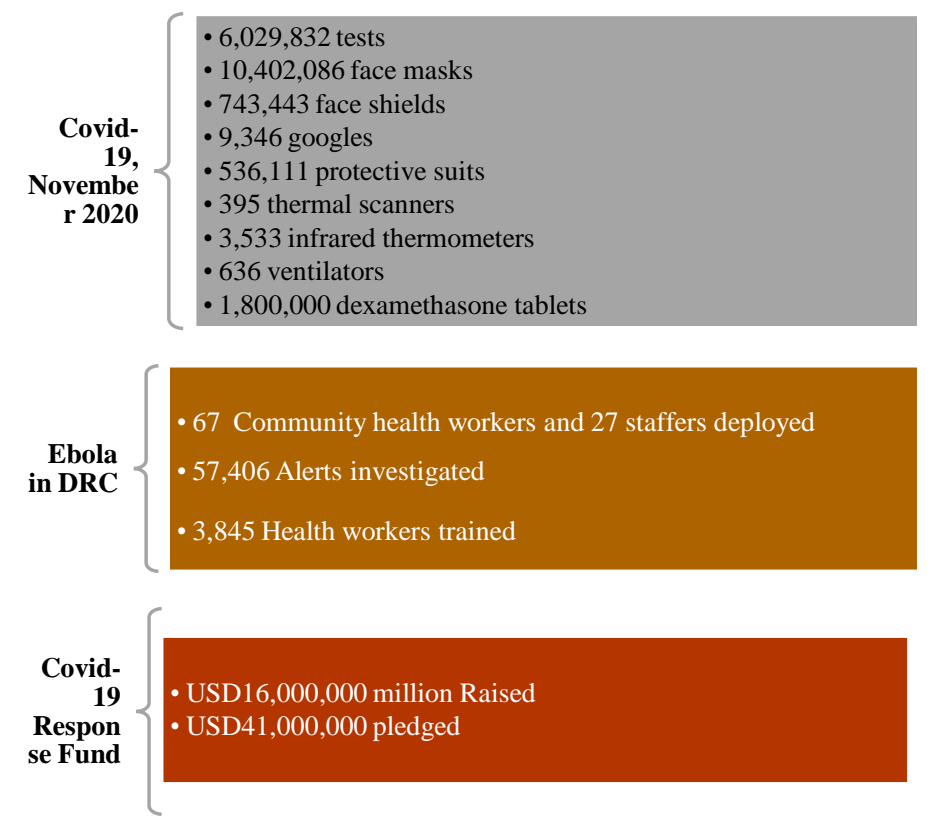

Fig.2AU Efforts in Harmonizing Health in the Region

Data Source: African Union Magazine; My Vision for the end of the Term 2021-2024, 2021

\section{2) Peace and Security}

\section{Sudan Experience}

In the Horn of Africa, after the Sudan military takeover in 2019, the AU intervened on accounts of unconstitutional change of government. To restore peace and democracy, the AU directed the military to hand over power in 25 days to a civilian-led government on a consensual transition (African Union, 2020). Although the AU Constitutive Act requires suspension of a Member State from AU activities in this context, it gave the country a three-month extension to allow further negotiations. AU was thus criticized for securing political transition while less engaged in safeguarding a civilian-led government path. On other accounts, AU contributed to the removal of Sudan from the list of state sponsors (Mahamat, 2021) of terrorism by the US, although this came at the cost of Sudan resuming its ties with Israel.

\section{Somalia Experience}

Although the African Union Mission in Somalia (AMISOM) is expected to elapse in 2021, Somalia-Kenya border disputes continue to intensify. This is despite IGAD's direction to Djibouti to lead a fact-finding mission into Somalia allegations of Kenya interfering with its internal affairs. These allegations were proven baseless in January 2021 report, although the official report has not been made public. Following the conflict in Gedo between the Somalia National and Jubaland forces, which led to the loss of lives, Kenya wrote to $\mathrm{AU}$ on the likelihood of escalating the already worse humanitarian crisis and complication on regional security. The AUC chairperson responded by calling for de-escalation of tension along the shared borders (African Union, 2021). The two States could use diplomacy to normalise their relations, but this will require Somalia's recognition of the 2009 Memorandum of Understanding which the International Criminal Court has recognized as a treaty (Ministry for Foreign Affairs, 2021).

\section{Intra-African Trade}

The AUC chair saw the African Continental Free Trade Area (AfCFTA) implementation in January 2021, later than the planned July 1st, 2019 launch. Under his guidance, AU established the AfCFTA secretariat in Accra, Ghana. "As of January 4, 2021, the Centre for Aviation reported on its website that the AfCFTA was under the implementation, and Ethiopia Airline and DHL commence operations under the under African Continental Free Trade Area". Countries with multiple memberships, primarily Southern and Central African States, have not yet submitted their ratification instrument to AU (Tralac, 2021). These States have also not yet tabled the agreement in parliament. Moreover, AU allowed Kenya to negotiate the UK-Kenya trade deal during the Heads of States Summit in 2019 on the basis that the deal will lay the basis for negotiation of other bilateral agreements between the African States and the UK. Ghana has signed a 
similar trade deal with the UK, although non-reciprocal (Department for International Trade, 2021).

Objective 2: Emerging Policy Issues in the Horn of Africa for the Term 2021-2024

\section{A. Border-Induced Disputes}

\section{1) Sudan-Ethiopia Al-Fashaga Border Dispute}

The upholding of Article 4(b) of the AU Constitutive Act has been a challenge to the African States in Horn and West of Africa. The 1,600 km long Al-Fashaga border continues to cause tension between Ethiopian and Sudanese governments. Ethiopia farmers have cultivated land that is claimed by Sudan, raising tension between the two States (Mules, 2021). In February 2021, Sudan agreed to hold negotiations with the Ethiopian government over the disputed land. In 2016, AU intervened by brokering a border demarcation in Al Fashaga to resolve the historical tensions but this effort did not materialize to long-term peace in the border. Although the Treaties of 1902 and 1907, international boundary lines put the land on Sudan's side, "As of 19 January 2021, according to $\mathrm{KII}_{1}$, Ethiopians have been living and cultivating in the area paying alliance to the Addis Ababa government". Any escalations of the dispute could affect the thousands of refugees who fled Tigray following the crisis in November 2020. Thus, the need for AU to adopt ways of intervening through the Early Warning Systems.

\section{2) Kenya-Somalia Diplomatic Rows over Jubaland}

$\mathrm{KII}_{3}$ stated that Kenya and Somalia are in severe diplomatic relations as Somalia continues to accuse Kenya of interfering with her 2020-2021 planned electoral process in the Southern States of Jubaland that borders Kenya. According to Menkhaus, (2011) Somalia has been in a war that occurred due to missed opportunities of 1989-1990. Amidst the accusations of 30 November 2020, Somalia expelled the Kenyan ambassador to Mogadishu. She recalled her ambassador in Nairobi just a month after the two countries commissioned the Somalia Embassy's reopening in Nairobi. Kenya had hosted the Jubaland President and the Somaliland president, holding bilateral talks with Somaliland in Nairobi (Ministry of Foreign Affairs 2020). Kenya and Somaliland agreed to cooperate on transport, trade, capacity development, agriculture, and livestock development (The Presidency, 2020).

\section{B. Election-Induced Disputes}

\section{1) Ethiopia}

Ethiopia is currently facing a crisis in Tigray and Oromo regions. The Tigray crisis, will have to be managed and peace rebuild in the country where the Oromo region is unstable after the 2020 crisis. Ethiopia's Addis government has refuted claims that the Tigray crisis has entirely affected humanitarian aid delivery, right to seek refuge and prevented the $\mathrm{AU}$ intervention based on Article 4(g) of the Constitutive Act of AU. ("As of January 5, 2021, the United Nations in its news website listed although the Government of Sudan continues to welcome refugees, UNHCR appealed for additional support to complement the authority's response"). The AU has on several occasions agreed and withdrawn the agreement for AU's intervention in the country. However, such intervention is technical as it is only possible with an invitation from the Ethiopian Government; Article 4(j). With the ongoing crisis in Tigray, the rights to Internally Displaced Persons (IDPs) according to the Kampala Convention Article III (10 (c, d, j) have not been upheld. The Eritrean refugees in Tigraran camps have been constantly attacked, and the UNHCR has not been able to deliver food to camps. Ethiopian forces restricted the refugees from entering Sudan. ("As of January 21, 2021, United Nations High Commissioner for Refugees on its website listed now, Haines and her colleagues are back, although for a short while until UNHCR receives authorization from the Government to fully return"). The Internally Displaced Persons not in areas controlled by the government have been denied delivery of food aid and other services since November 2020. The African Union report of 2020 stated that the Tigrarian conflict could have been prevented if the early warning systems intervened in time (African Union, 2021). This comes as AU had called for a dialogue in early November 2020, which was refuted by the Addis federal government based on international interference to 'law enforcement operation.' Although Ethiopia holds AU council seat until 2022, AUPSC could feature the crisis into its plan to redeem the organ's reluctance in previous cases in Cameroon, Uganda, Nigeria, among others. AU could also support the United Nations (UN) and the European Union (EU)'s call for unconditional and unrestricted access of humanitarian aid and personnel to Tigray and allow independent investigations into allegations of grave violations in the region.

\section{Upcoming Volatile Elections in the Horn of Africa}

\section{1) Somalia Postponed Elections}

Elections in the Horn of Africa have been characterized by bloodshed, looting, violence, and slow economic activities. First, Somalia's expected February $8^{\text {th }}$ election did not materialize. It caused the opposition to declare the current Mogadishu president's term of office illegitimate. Somalia practices indirect elections where clan members nominate parliamentarians who, together with the 59 senators elected by the state assemblies, select the president. However, according to $\mathrm{KII}_{3}$, the system has been vulnerable to al-Shaabab influence directing Somalia to conduct one person-one ballot elections in 2021. As of 24 February 2020, the move was termed by the United Nations Security Council (UNSC) as a historic milestone on a long journey back to security and stability. However, as elections drew near, the federal regions' presidents were concerned about the president's run for a second office, which was evident in the fueled dispute between Mogadishu, Jubaland, and the taking over Gedo. 
AU will have to keep watch of Somalia's elections as any severe dispute between the leaders will jeorpadize the AU's mission on peacekeeping, whose contract is set to expire in February 2021 and likely withdrawal in 2021. Besides, the UNSC and the European Union (EU)'s funding of the mission expiry March $14^{\text {th }}$ (UNSC, 2021) and July 2021, respectively, puts the missing achievement at risk. Intergovernmental Authority on Development (IGAD) will not be eligible to watch Somalia's elections as Somalia has already raised claims of the community's integrity and alliance with Kenya. AU has to recognize and act on the Somalia Transition Plan's success (United Nations Security Council, 2020) that AUPSC endorsed in April 2018. Also, leaving Mogadishu volatile will create a favorable environment for the al-Shaabab militia to operate in the region, creating security expenditure pressure on Kenya as it tries to secure its borders and protect its people. Thus, the need for Kenya and Somalia to re-negotiate bilaterally in an effort to continue the peacekeeping beyond AMISOM.

\section{2) Ethiopia's June 2021 Elections}

Secondly, Ethiopia's elections set for 5 June 2021 is will likely be characterized by violence as the country has been in constant conflicts between the capital administration and the federal States. The Tigray crisis started as a ripple effect of postponement of the August 2020 parliamentary elections tied to the Covid-19 pandemic and a constitutional dispute on the Tigray's right to conduct elections autonomously as listed on the Foreign Policy website on 29 December 2020. In Ethiopia, there is the need to find a power balance between the regions and the federal government. Without integrity, the election process will lose legitimacy, and the government will lose trust from its loyal regions leading to more destabilizing. For Ethiopia to transition to democracy, there is the need for civic education efforts aimed at instilling the knowledge that democratic elections require different presidential candidates with a competitive vision and ideas. Ethiopia has over 100 political parties, all competing for the parliamentary system. Most of them have never competed in a national election before (International Crisis Group, 2021), and thus the outcome of the inexperienced multi-party competition is unpredictable. Moreover, given the volatility of cooperation between the regions and the federal government, the electoral environment is expected to remain fluid even after the elections. AU has not been engaged in the Tigray crisis, and thus, its intervention in the Ethiopian elections ${ }^{1}$ due June 2021 remains unknown. The AUC chairperson could use this opportunity to deliver on his Vision of African solutions for African problems between African and by Africans (African Union, 2021).

\section{Resource-Based Disputes}

\section{1)Horn of Region}

Locust invasion in the Horn of Africa remains a threat to a region whose cooperation is based on food security and prevention of drought besides economic cooperation. The
Horn of Africa has been characterized by drought and famine since 1991/92 and has constantly worsened the inter-clan wars and border-community conflicts as communities struggle for resources. $\mathrm{KII}_{2}$ noted that the current locust invasion in the Horn is an early warning of famine and drought in the region characterized by pastoralist communities who compete for inadequate pasture. The swarm has been attributed to Cyclone Mekunu of 2019, which produced heavy rains. Later in 2019, the swarms spread, and by June, there were already attacking crops and vegetation in the Horn of Africa. Currently, the second wave is despairing farmers in Somalia (area affected by cyclone Gati), Ethiopia, Kenya, and Uganda (Food and Agriculture Organization, 2021)

Although the concerned governments have devised measures to curb the locusts' spread, a lot remains undone. As of 13 February 2020, the Food Agricultural Organization reported on its website that through cooperation with the Kenya Ministry of Agriculture in collaboration, Kenya has set aside USD30 million to fight the second wave of locusts, nine surveillance and spray aircraft, 21 vehicles mounted with sprayers, and trained 500 National Youth Service personnel). On the other hand, Somalia issued a state of emergency in February 2021 though not yet developed measures to curb the spread. In this regard, AU could cooperate with the concerned countries, the World Bank, Desert Locust Control Organization of East Africa (DLCO-EA), IGAD, FAO, and World Food Programme (WFP), as well as the local NGOs with established knowledge of desert control.

\section{2) Sudan}

Sudan's Darfur conflicts are based on natural resources that actors exploit to help them gain power and influence over Khartoum. Intervening in Sudan's Coup D'etat of 11 April 2019, AU requested stakeholder engagement from IGAD and ACHPR towards modalities for investigating the deadly events of June 2019. The Coup D'etat later saw Sudan suspended from AU activities (African Union, 2019). Although AU has distanced itself from efforts to stabilize the country, it led the transition to the civilian-military interim government and the October 2020 Juba Peace agreement AUUN (UNAMID) hybrid mission in Darfur. $\mathrm{KII}_{1}$ noted that the withdrawal of UNAMID is likely to leave a vacuum in the fragile State. Therefore, AU will have to reintervene in Sudan to ensure a successful transition to democracy.

\section{3) Kenya}

The Kapedo land-based conflict occurs in a region whose economic activity is farming; Baringo, Turkana, West Pokot, and Samburu. Kapedo town borders both Turkana and Baringo counties, with each claiming the town. According to $\mathrm{KII}_{2}$, although the government has used different approaches to curb insecurity in the region, such as disarmament, the root cause is yet to be tackled. Moreover, the proliferation of arms and political actors plays a role in a region whose past has been characterized by cattle rustling. Thus, these actors are inciting conflict to gain control over Kapedo waterfalls that 
merge with the Suguta River forming a huge farming potential and a treasurable resource in the middle of a semi-desert. Currently, the Geothermal Development Company (GDC) has geothermal wells in the Baringo-Sale. Due to the ongoing insecurity in the region, schools have been closed while shops are dry of food, thus staring at a humanitarian crisis. Despite Kenya's government deploying security personnel, commissioning a fact-finding mission, and administering the region with Tiaty sub-county (Pokot) and Turkana East Subcounty chiefs, insecurity remains rampant as the community continues to hold guns. On its flagship on silencing the Guns by 2023, African Union could also focus on Kenya's Kapedo insecurity.

\section{E. Diplomatic Challenges}

\section{1) GERD Negotiations}

AU has been instrumental in negotiating over the Nile dam dispute between Ethiopia, Sudan, and Egypt. The AU bureau group of five leaders was given the legitimacy to intervene in peace and security and mediated a tense dispute over the Grand Ethiopia Renaissance Dam (GERD) (International Crisis Group, 2020). Ethiopia has commenced on the second phase of the project, which it argues will improve lives in the region. The GERD dispute is based on the 1959 agreement that allocated all the Nile River's waters to Egypt and Sudan, leaving 10 cubic meters for seepage and evaporation and none to Ethiopia. AU has resolved many issues associated with the dispute, and the three countries agreed that a drought would be inevitable when the flow of the water to the dam falls below 35-4o b.c.m per year. In such a case, Egypt and Sudan, Ethiopia would have to release some of the dam's waters to deal with such drought. According to $\mathrm{KII}_{1}$, the controversy over the dam has intensified the relations among the States as Ethiopia prefers the flexibility to deal with the drought on its own. AU, therefore, needs to intervene to straighten the Vision of the three involved actors, focusing on the impact of the project on the people of the land.

\section{F. External Actors in the Horn of Africa}

\section{1) External influence}

The three key informants stated that external actors have created military, political, and economic pressure in the Horn of Africa. Actors such as Qatar and Turkey have strongly supported Somalia President Farmajo, while UAE has supported the five federal member states in the country's political dynamics. The strategic positioning of the Indian Ocean and the Gulf of Eden network of ports and trade routes has attracted China, Turkey, France, and UAE, all with different national interests in the region. Furthermore, the aftermath of Arab Spring, which was first felt in Egypt and Libya in 2019, has spilled over to Sudan and Somalia, with the Arab States positioning themselves with federal and national governments. As the actors strive to advance resource-control over oil, trade route, and gas in the Horn (Bahgat, 2015), AU could cooperate with national governments to ensure that aid-seeking partnerships signed are honest and mutual for the African low-income States.

\section{Objective 3: Policy Recommendations}

The AU Member states could strengthen Article 4(j) and Article 32 to give the inter-governmental body power to intervene in a humanitarian crisis with or without government intervention. For the AU's report for the year 2020, which advocated for RECs to lead election monitoring and observation while $\mathrm{AU}$ to provide pre-and post-electoral technical assistance, to be successfully implemented, political will has to be strengthened across the African States.

\section{REFERENCES}

Communiques

[1]. African Union. (2019). Communique adopted by the Peace and Security Council at its 854th meeting held on 6th June 2019, on the situation in Sudan, Addis Ababa: African Union.

[2]. African Union. 2020. Communique adopted by the Peace and Security Council at its 840th meeting held on 15th April 2019 on the situation in Sudan, Addis Ababa: African Union.

[3]. Department for International Trade. (2021). Ghana-UK joint statement: Ghana-UK trade partnership agreement. Press release, UK. $\quad$ Retrieved from https://www.gov.uk/government/news/ghana-uk-jointstatement-ghana-uk-trade-partnership agreement\#: :text=Today\%20Ghana\%20and $\% 20$ the $\% 20 \mathrm{UK}$,ex porters $\% 20$ to\%20the $\% 20$ Ghanaian\%20market.

[4]. ECOWAS Commission. (2021). Communique of the ECOWAS evaluation mission on the ongoing transition in Mali, Bamako: ECOWAS Commission Economic Community of West African States.

[5]. Ministry of Foreign Affairs. (2020). Somalia reopens its embassy in Kenya, Nairobi: Ministry of Foreign Affairs, Kenya.

[6]. Peace and Security Council. (2020). Communique adopted by the Peace and Security Council (PSC) of the African Union (AU), at its 941st meeting. Addis Ababa: Ethiopia.

[7]. Peace and Security Council. (2019). Communique adopted by the Peace and Security Council at its 840th meeting held on 15th April 2019 on the situation in Sudan, Addis Ababa: Ethiopia.

[8]. The Presidency. (2020). Joint communiqué issued by His Excellency Uhuru Kenyatta, President of the Republic of Kenya and His Excellency Muse Bihi Abdi, President of Somaliland, on the occasion of the official visit to Kenya from 13th to 14th December 2020. Retrieved from https://www.president.go.ke/2020/12/15/joint-communiqueissued-by-his-excellency-uhuru-kenyatta-president-of-therepublic-of-kenya-and-his-excellency- muse-bihi-abdipresident-of-somaliland-on-the-occasion-of-the-official-visit-tokenya-f/

[9]. Ministry for Foreign Affairs. (2021). Press statement on the maritime delimitation case (Somalia vs. Kenya) at the International Court of Justice 15th-24th March 2021. No 6. Retrieved from https://www.mfa.go.ke/?p=3759

[10]. United Nations. (2020). Security Council 8731st meeting; Somalia's 2020 elections will be historic milestone on long journey back to security, stability; special representative tells Security Council: United Nations Security Council.

Treaties and Agreements

[11]. African Union. (2010). African Union Convention on the Protection and Assistance of Internally Displaced Persons in Africa, Kampala: African Union 
Reports

[12]. African Union. (2020). Africa Joint Continental Strategy for Covid-19 outbreak. Addis Ababa: African Union.

[13]. African Union. (2021). Statement by His Excellency Hon. Uhuru Kenyatta, C.G.H, President of the Republic of Kenya and Commander-In-Chief of the Defence Forces during the Annual Presidential Briefing to the Diplomatic Corps on Thursday, 4th March 2021 at state house, Nairobi. Nairobi: Kenya.

[14]. African Union (2021). Taking stock, charting the future; African Union Commission end of term report 2017-2021. Addis Ababa: African Union.

[15]. Bahgat G. (2015). "Egypt in the aftermath of arab spring. What lies ahead" International Crisis Group. Conflict's trend 2015/1. https://www.accord.org.za/conflict-trends/egypt-aftermatharab-spring/

[16]. Energy Information Administration. (2019). The Bab elMandeb Strait is a strategic route for oil and natural gas shipments. Report for the US energy information administration, Washington DC: UK

[17]. Food and Agriculture Organization. (2021). Desert locust bulletin; General situation during January 2021 forecast until mid-March 2021. Nairobi, Food and Agriculture Organization of the United States issue No.508.

[18]. International Crisis Group. (2021). Eight priorities for the African Union in 2021, Addis Ababa: Ethiopia.

[19]. International Crisis Group. (2021). Finding a path to peace in Ethiopia's Tigray region. Briefing No 167/ Africa, 11th February. Retrieved from https://www.crisisgroup.org/africa/horn-africa/ethiopia/167finding-path-peace-ethiopias-tigray-region

[20]. Mahamat, F. M. (2021). My vision for the end of the term 2021-2024. Addis Ababa: Ethiopia.
[21]. Menkhaus K. (2011). World development report 2011; Somalia and the Horn of Africa: World Bank.

[22]. Menkhaus K. (2011). World development report 2011; Somalia and the Horn of Africa: World Bank.

[23]. Tralac. (2021). Infographics: Status of AfCFTA ratification: Tralac

[24]. United Nations Security Council. (2020). Resolution 2520 (2020) Adopted by the Security Council on 29th May 2020, New York: New York, UK.

[25]. United Nations Security Council. (2021). February 2021 monthly forecast, Africa Somalia. New York, UK.

Books

[26]. Moravcsik, A. and Schimmelfennig F. (1993). Liberal intergovernmentalism, in A. Wiener, A. B. Tanja, and R. Rhomas (ed), European integration theory. Oxford: Oxford University Press.

Articles

[27]. Obulutsa G. (2021). Africa secures 400 million more Covid-19 vaccine doses. Retrieved from https://www.reuters.com/article/us-health-coronavirus-africaidUSKBN29X1CE

[28]. Rossiter, A., and Cannon, B. J. (2019). "Re-examining the base. The political and security dimensions of turkey's military presence in Somalia". pp. 167-188 JSTOR. Retrieved from https://www.jstor.org/stable/26776053

[29]. Wiebusch, M., Aniekwe, C.C., Oette, L., and Vandeginste. 2019. "The African Charter on Democracy, Elections and Governance: Trends, challenges and perspectives" p 99. Sagepub. Retrieved https://doi.org/10.1177/0002039719896109 